\title{
TAXONOMY OF BEGONIA SEROTINA (BEGONIACEAE) AND ALLIED SPECIES
}

\author{
M. C. Tebitti ${ }^{1}$, C. E. Toapanta A. ${ }^{2} \&$ Á. J. Pérez
}

\begin{abstract}
An emended description of the poorly known Begonia serotina A.DC. (Begoniaceae) is provided and $B$. asympeltata L.B.Sm. \& Wassh. is newly synonymised with that species. The classification of Begonia serotina in B. sect. Knesebeckia (Klotzsch) A.DC. is confirmed. Begonia compacticaulis Irmsch. is shown to be a synonym of $B$. ludwigii Irmsch., while the circumscription of B. compacticaulis in the Flora of Ecuador is shown to be based on specimens of both B. ludwigii and B. serotina. Begonia serotina is more widely distributed than previously recorded and is newly reported from Ecuador's Los Rios, Bolivar and Loja provinces and Peru's Tumbes region. Begonia serotina is reassessed as Vulnerable (VU), according to IUCN criteria.
\end{abstract}

Keywords. Begonia asympeltata, Begonia compacticaulis, Begonia ludwigii, Begonia sect. Knesebeckia, Begonia serotina, Ecuador, Peru.

\section{INTR ODUCTION}

Begonia serotina A.DC. is a poorly known member of its genus. Alphonse de Candolle's (1859) original diagnosis of this species was based on a single collection, Jameson 594, made at Cerro Santana in Guayas Province, Ecuador. In his 1864 account of the Begoniaceae for the Prodromus, de Candolle presented a slightly more detailed diagnosis but again cited only the type collection. The only detailed published description of this species appears in the Begonia account for the Flora of Ecuador (Smith \& Wasshausen, 1986) but even this account cites just four herbarium collections, including the type collection. The four collections were made in the Ecuadorian provinces of Manabí, Guayas, Cotopaxi and Chimborazo.

The classification of Begonia serotina has been changed twice since the species was first described. De Candolle $(1859,1864)$ first classified Begonia serotina in B. sect. Huszia (Klotzsch) A.DC. Later, Smith \& Wasshausen (1979) transferred Begonia serotina to B. sect. Begonia, and then Doorenbos et al. (1998) classified it in B. sect. Knesebeckia [which Smith \& Wasshausen (1979) had included within B. sect. Begonia]. A forthcoming monograph of Begonia sect. Eupetalum (Tebbitt, in prep.) will recognise modified circumscriptions of both $B$. sect. Eupetalum [which currently includes

\footnotetext{
1 Department of Biological and Environmental Sciences, California University of Pennsylvania, California, PA 15419-1394, USA. E-mail for correspondence: tebbitt@calu.edu

2 Herbario QCA, Escuela de Ciencas Biológicas, Pontificia Universidad Católica del Ecuador, Apartado 17-01-2184, Quito, Ecuador.
} 
B. sect. Huszia (Doorenbos et al., 1998)] and the closely related B. sect. Knesebeckia. Begonia sect. Eupetalum will contain perennating herbs with perennial tubers and relatively large flowers, while $B$. sect. Knesebeckia will contain herbs or subshrubs with perennial above-ground parts, which lack tubers, and have relatively small flowers. In order to determine which of these two sections Begonia serotina should be classified in it is, therefore, necessary to ascertain whether this species has either a perennating tuber or a perennial above-ground stem.

Different authors probably classified Begonia serotina in different sections because they interpreted the basal parts of the herbarium material in different ways. De Candolle $(1859,1864)$ did not mention the presence of tubers in his diagnoses of Begonia serotina, although he classified it in his B. sect. Huszia, which he distinguished from other South American sections by the combination of its species' acaulescent habits, tubers and dichotomous cymes. Smith \& Wasshausen (1986, p. 42) described Begonia serotina as 'caulescent from a subglobose strongly fibrillose tuber $13 \mathrm{~mm}$ in diam.'. Doorenbos et al. (1998) stated that the species was rhizomatous. Smith \& Wasshausen's (1986) observation would suggest the species requires transferring to Begonia sect. Eupetalum, as also would its original placement in B. sect. Huszia since that section is currently included as a synonym of $B$. sect. Eupetalum. Conversely, Doorenbos et al.'s (1998) interpretation would suggest that the species is correctly classified in Begonia sect. Knesebeckia. Examination of herbarium material of Begonia serotina in the current study found that the dried basal portion of this species was very difficult to interpret. Consequently, Begonia serotina was examined in the field in order to determine whether it had tubers or perennial above-ground parts. Examination of five wild populations showed that Begonia serotina lacks tubers and has an unusual, perennial, thickened, above-ground stem that typically grows horizontally along a rock face or occasionally in soil for several centimetres but will then grow upwards for a short distance and produce leaves and inflorescences at its apex. Tebbitt included a colour photograph (2014, fig. 9) showing the unusual habit of Begonia serotina. It is easy to see how past authors, with only herbarium material available, mistook the thick, horizontal part of the stem for a portion of an underground tuber. The absence of tubers, coupled with the species' persistent aerial stem and small flowers, confirms its placement in Begonia sect. Knesebeckia and excludes it from B. sect. Eupetalum.

Smith \& Wasshausen (1979) described Begonia asympeltata based on a single specimen, Harling 201, collected at Hacienda Clementina, Los Rios Province, Ecuador. Fieldwork has shown that this type specimen only differs from Begonia serotina (Fig. 1) in having a leaf blade margin with serrate teeth as well as denticulate teeth (Fig. 2). The leaf margin of Begonia serotina is denticulate but not serrate. Smith \& Wasshausen (1979) in their original description of Begonia asympeltata additionally distinguished this species from $B$. serotina by its ovate leaf blades (vs. orbicularovate in $B$. serotina) and leaf bases that are particularly strongly emarginated, giving the blade a slightly asymmetric shape. Fieldwork has shown that both these features are occasionally seen within large populations of Begonia serotina. Since 


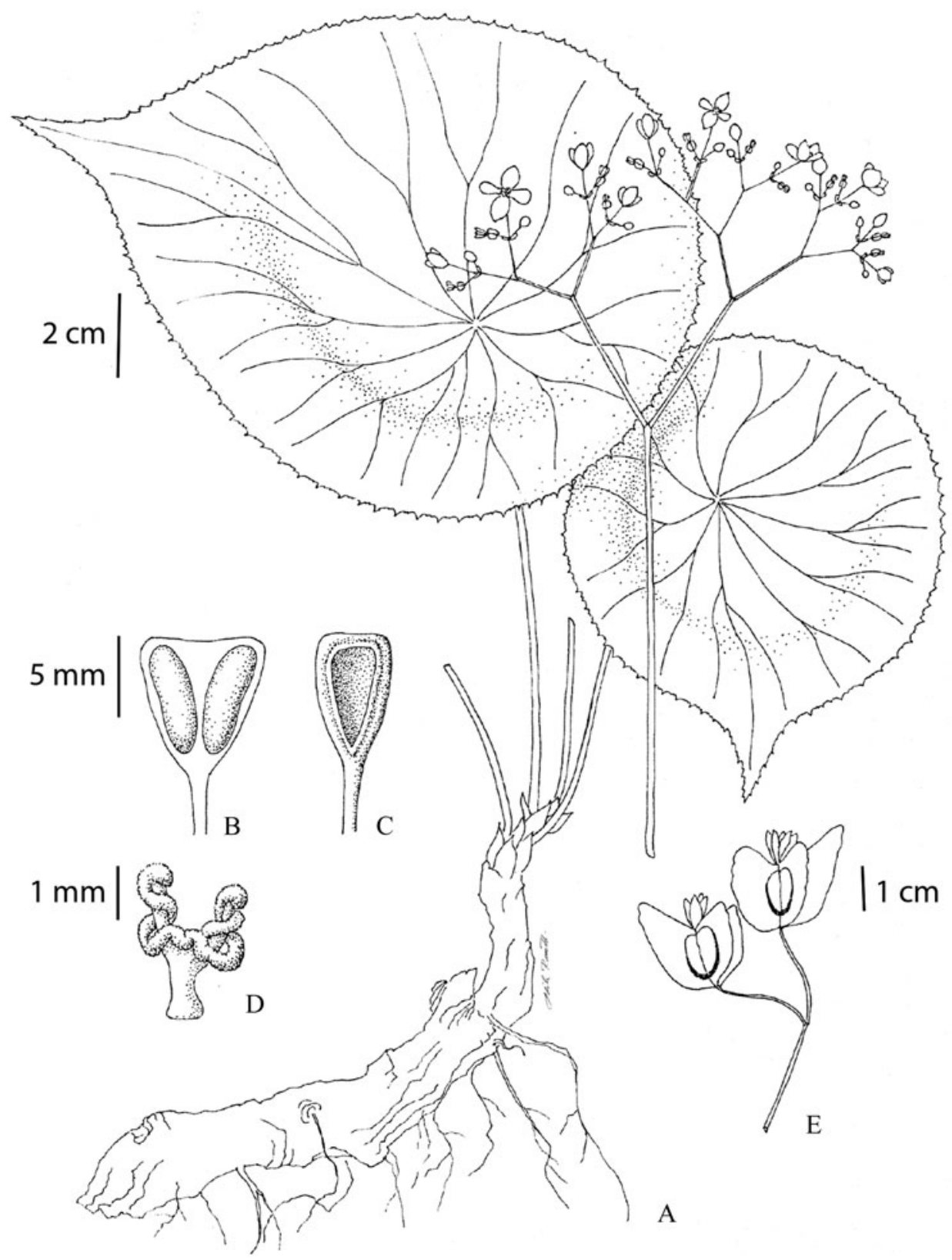

FIg. 1. Begonia serotina A.DC. A, habit; B, stamen (front view); C, stamen (side view); D, style; E, branch of infructescence. Drawn from J. Madsen 61182 (AAU).

the only reliable characteristic that separates Begonia asympeltata from B. serotina is the depth of the teeth on the leaf blade margin, the two are recognised here as being conspecific. 

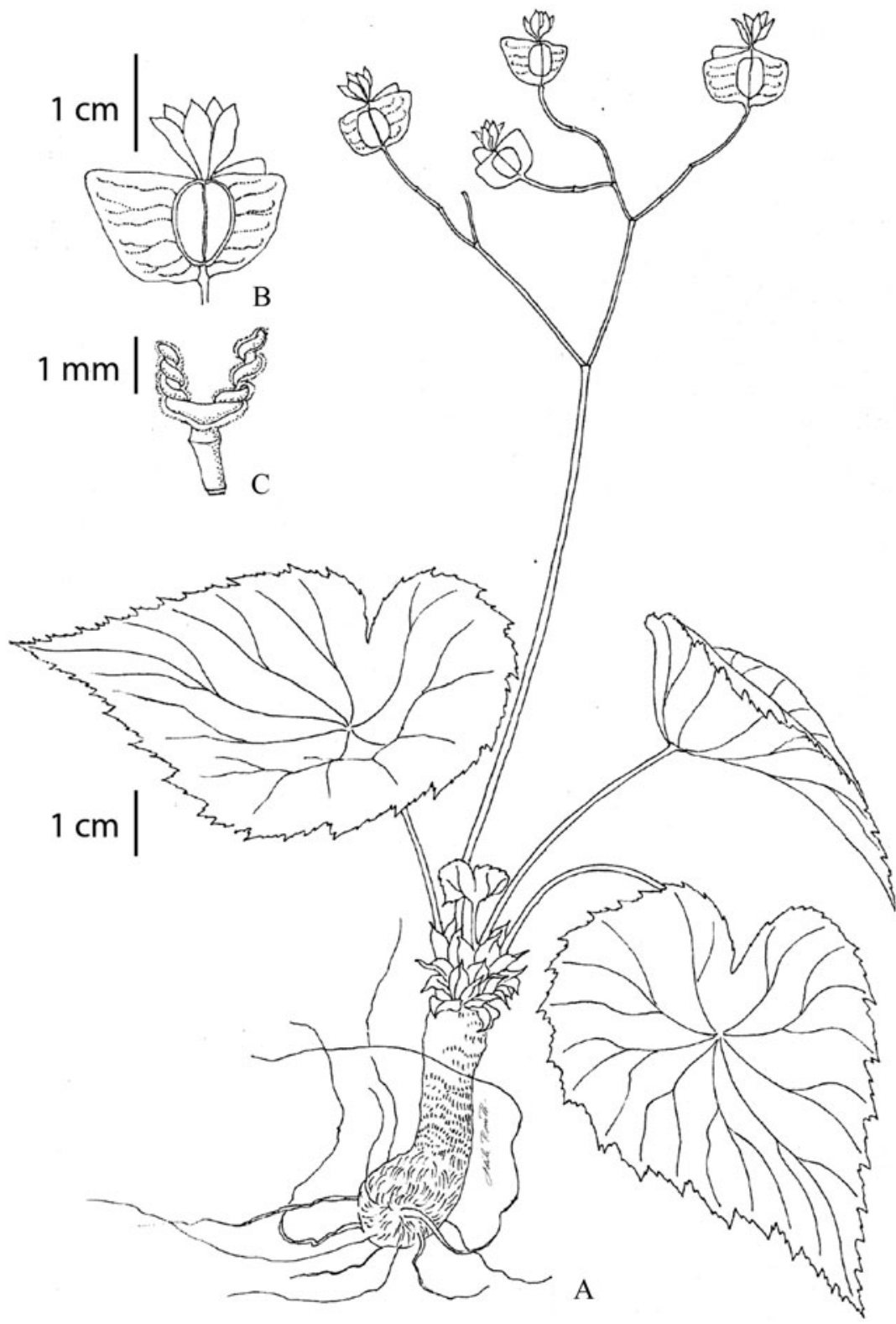

FIg. 2. Begonia serotina A.DC. A, habit; B, fruit; C, style. Drawn from G. Harling 201 (S) (= holotype of B. asympeltata L.B.Sm. \& Wassh.).

Begonia compacticaulis Irmsch. was also targeted during recent fieldwork. The species has been recorded only from the Ecuadorian provinces of Cotopaxi and Chimborazo (Smith \& Wasshausen, 1986). Detailed searches of all three collection localities in Chimborazo Province cited by Smith \& Wasshausen (1986) failed to 
locate any plants matching the combination of characters found in the four specimens that they list: Hitchcock 20315, Øllgard \& Balslev 9007, Camp E-3862, and Dodson et al. 13933. Instead, both Begonia serotina and B. ludwigii Irmsch. were located at each site, prompting a critical re-examination of the herbarium material. It was subsequently found that the collection upon which Irmscher (1949) had entirely based his description of Begonia compacticaulis, Hitchcock 20315, is conspecific with B. ludwigii. This material was probably previously misidentified because the holotype and isotype both lack most of their stems, as well as their leaves and female flowers. It is notable that the fragments of thick aerial stems that are present on both type specimens bear large leaf scars since these are diagnostic of Begonia ludwigii. The collection Øllgard \& Balslev 9007 (AAU, NY) also represents B. ludwigii. It too lacks leaves (as is typical of Begonia ludwigii at anthesis) but again has the characteristic thick stem with large leaf scars of $B$. ludwigii, as well as ovaries bearing bracteoles, which is another unusual characteristic found in B. ludwigii. Tebbitt included a colour photograph (2014, fig. 8) of Begonia ludwigii growing at the site where Øllgard \& Balslev 9007 was collected. Camp E-3862 also represents Begonia ludwigii, while Dodson et al. 13933 represents $B$. serotina. This latter collection is the only one that Smith \& Wasshausen (1986) cited that has leaves, although they did not describe the leaves of Begonia compacticaulis and their illustration of this species is leafless. The specimens of Dodson et al. 13933 are damaged making it difficult to observe the morphology of the leaf blades but careful examination found that the leaves of these specimens are peltate as is characteristic of Begonia serotina. It is also significant that the specimen of Dodson et al. 13933 at SEL has fruit and these lack bracteoles, since Begonia serotina lacks bracteoles, while $B$. ludwigii has bracteoles.

Within the genus Begonia, seed micromorphology is often of taxonomic value (de Lange \& Bouman, 1992, 1999). Seeds from two herbarium collections previously determined as Begonia serotina (Camp 3716 [MO]; Diaz et al. 4708 [MO]) and one herbarium collection previously determined as B. compacticaulis (Dodson et al. 13933 [SEL]) were examined to see whether any features of their micromorphology either supported or refuted the merging of these two taxa. Approximately ten seeds from each of the three accessions studied were coated with platinum for four minutes using an Anatech Hummer VI-A sputter coater. Prepared seeds were then examined with a Jeol JSM-5300 scanning electron microscope (SEM). Seeds of all three accessions were found to be of the typical seed type found in Begonia (de Lange \& Bouman, 1992, 1999) and did not differ significantly from one another. All three accessions, however, differed from the norm by having testa cells with slightly undulate walls, supporting the hypothesis that they belong to a single taxon.

\section{TAXONOMIC TREATMENT}

Begonia serotina A.DC., Ann. Sci. Nat., Bot., IV, 11: 121 (1859). - Type: Ecuador, Cerro of Santana, Guayaquil, v 1846, W. Jameson 594 (holo G-DEL; photo NY!; iso G-DC! (photos F!; MO! negative \#8519); K!; MO!; OXF!). Figs 1, 2. 
Begonia asympeltata L.B.Sm. \& Wassh., Phytologia 44: 244, pl. 6 (1979). - Type: Ecuador, Prov. Los Rios, Hacienda Clementina, 27 i 1947, G. Harling 201 (holo S!), syn. nov.

Begonia parmata Irmsch., Bot. Jahrb. Syst. 74: 611 (1949). - emend. Irmsch., Bot. Jahrb. Syst. 76: 90 (1953). - Type: Ecuador, Tal des Rio Chanchan, bei Naranjapata, 25 ix 1933, L. Diels 1213 (holo B!).

Begonia compacticaulis auct. non Irmsch.: L.B.Sm. \& Wassh. in G. Harling \& L. Andersson (eds) Flora of Ecuador 25: 38 (1986), pro parte.

Caulescent herb; stem to $35 \mathrm{~cm}$ long, basal portion producing roots along its length and either growing pressed against a rock face or in soil, apical portion aerial for up to $20 \mathrm{~cm}, 0.8-2.5 \mathrm{~cm}$ diam., stem unbranched or the aerial portion with one or two short branches; stipules persistent, ovate, $1.1-1.3 \times 0.4-0.8 \mathrm{~cm}$, apex acute, aristate, margin entire. Leaves few, deciduous in dry season [Haught 3090], spirally clustered towards the stem apex, peltate; petioles $5-40 \mathrm{~cm}$ long, glabrous to puberulent; lamina subsymmetric, usually orbicular-ovate, occasionally ovate [e.g. Harling 201], 6.5-19 $\times$ 4-20.5 cm, juicy, upper surface usually deep green or rarely with green veins and margin and purplish-brown intervenal lamina [Tebbitt 794], glabrous or puberulent, lower surface pale green, glabrous or sparsely pubescent, apex abruptly acuminate, margin usually denticulate, rarely serrately toothed as well as denticulate [Harling 201], teeth typically $0.25-1 \mathrm{~mm}$ long, with a short hair at the tip and along sides of the teeth, veins radiating out from central point, 8 to 9. Inflorescences: 1 to 4, axillary, arising from apical portion of rhizome or from short side branches of main rhizome, held erect, a dichasial cyme, branching up to six times, many-flowered, flowers predominantly male, protandrous; peduncle $19-52 \mathrm{~cm}$ long, primary branches $1.5-9.5 \mathrm{~cm}$ long, secondary branches $0.5-3.3 \mathrm{~cm}$ long, glabrous; pedicels of male flowers $0.3-1.4 \mathrm{~cm}$ long, glabrous; pedicels of female flowers $0.7-2.6 \mathrm{~cm}$ long, glabrous; bracts deciduous, narrowly elliptic-ovate to ovate, $1-5(-12) \times 0.75-3(-7) \mathrm{mm}$, apex subacute, margin entire. Male flowers: tepals 4, spreading, white, white with pale pinkish veins, pink, pale red or cream-yellow, glabrous, margins entire, outer pair oblong-elliptic, elliptic, or ovate, $0.6-1.4 \times 0.4-0.65 \mathrm{~cm}$, apex obtuse, base rounded to subcordate, inner pair spathulate, $4.7-7.7 \times 2-4.5 \mathrm{~mm}$, apex obtuse, base tapering; stamens 35 to 60 , attached along the length of a $0.5-1 \mathrm{~mm}$ tall torus and also around base of torus; filaments $1-2 \mathrm{~mm}$ long; anthers obovate, $0.5-1 \mathrm{~mm}$ long, dehiscing by unilateral slits, connectives widening at apex but not projecting, symmetrically basifixed. Female flowers: bracteoles absent; tepals persisting in fruit, 5, spreading, same colour as males, glabrous, margins entire, outer 4 obovate-elliptic, elliptic, or ovate, 4-7.5 $\times 2.5-4 \mathrm{~mm}$, apex acute or subacute, base rounded, innermost narrowly elliptic, 3.75-7.5 $\times 1.8-2.6 \mathrm{~mm}$, apex subacute, base rounded; ovary body ellipsoid, $0.6-1.1 \times 0.4-0.6 \mathrm{~cm}$, initially white with a pink tinge but becoming pale green, glabrous, subequally 3 -winged, wings subdeltoid, front edge of wings \pm truncate to shallowly convex curved forward over styles, from there slightly curving downwards until in line with base of ovary body and then at a steeper angle curving c. $2 \mathrm{~mm}$ past base of ovary to meet pedicel, apex 
obtuse, 1-4 × 7-16 mm, 3-locular; styles 3, free to base, 1.5-4 mm long, bifid from about $2 / 3$ their height, branches \pm erect, stigmatic papillae in a spiral band. Fruiting pedicel elongating and up to $2.5 \mathrm{~cm}$ long. Fruit erect, body broadly ellipsoid, to $1.3 \times$ $1 \mathrm{~cm}$, glabrous, wings same shape as in ovary, to $1.5 \times 2.1 \mathrm{~cm}$, apex obtuse, shorter two wings to $1 \mathrm{~cm}$ long and $2.1 \mathrm{~cm}$ wide, apex obtuse. Seeds ellipsoid, 265-366 $\times$ 154-192 $\mu \mathrm{m}$; collar region occupying 1/2 of seed length; operculum nipple-shaped, 35-62 $\mu \mathrm{m}$ long; testa cells 2 along long axis of seeds; walls of testa cells slightly undulate, cuticle of collar and testa cells covered with undulated striae, the striae of the collar cells 2-20 $\mu \mathrm{m}$ long.

Phenology. Flowering year-round.

Distribution. East central and southeastern Ecuador (Manabi, Cotopaxi, Los Rios, Bolivar, Chimborazo, Guayas, El Oro, Loja) and northern Peru (Tumbes).

Habitat. Growing in primary and secondary forests both in Ecuador's coastal lowlands, where it often occurs in wet microhabitats within dry forest, and also along the base of the neighbouring Andean foothills in both dry and humid forest, at altitudes of 25 to $1200 \mathrm{~m}$. In Peru, known from a single collection from the base of the Andean foothills at an altitude of $720 \mathrm{~m}$. Rupicolous, terrestrial or occasionally epiphytic, but typically on or at the base of moist cliffs, in shaded situations usually by streams and rivers.

IUCN conservation category. Quintana \& Pitman (2003) previously assessed Begonia serotina as Endangered A4c ver. 3.1 based on its known occurrence from several populations occurring in the Ecuadorian provinces of Manabi, Cotopaxi, Chimborazo, Guayas and El Oro. Despite having protected populations in the Parque Nacional Machalilla, the species was considered endangered because it was found in Ecuador's coastal forests, which have witnessed extensive deforestation during the last century. The present study has increased the known distribution of this species to include Los Rios and Loja provinces of Ecuador and the Tumbes region of Peru, the latter population of which occurs within a protected area. Begonia serotina is newly assessed here as Vulnerable (VU), according to IUCN criteria (2012). This revised designation is based on the extended known distribution for the species coupled with the observation of several large populations of the species along the base of Ecuador's Andean foothills in which seedling recruitment was widely evident. While locally common, Begonia serotina is considered Vulnerable because most of its former lowland populations have been extirpated by habitat destruction, and the species is continuing to decline due to ongoing habitat destruction.

Additional specimens examined. EcuAdor. Junction of the Provinces of Guyas, Cañar, Chimborazo and Bolivar, foothills of the western cordillera near the village of Bucay, 8-15 vi 1945, W.H. Camp 3716 (F, K [2], MO, NY, US). Manabí: Road Portoviejo-Pichincha, 3 km E San Plácido, $1^{\circ} 1^{\prime} \mathrm{S}, 80^{\circ} 5^{\prime} \mathrm{W}, 6$ v 1985, G. Harling \& L. Andersson 24887 (QCA); Humid cloud forest of San Sebastián, in the vicinity of Agua Blanca, c.15 km of Puerto Lopéz, area of Jipijapa, $1^{\circ} 28^{\prime} \mathrm{S}, 80^{\circ} 47^{\prime} \mathrm{W}, 20-22$ xi 1987, F. Hekker \& W.H.A. Hekking 10225 (AAU, US); San 
Sebastián, Machalilla National Park, $1^{\circ} 36^{\prime} \mathrm{S}, 80^{\circ} 42^{\prime} \mathrm{W}, 21$ i 1991, A. Gentry et al. 72568 (MO); Cuenca del río Ayampe, Cerro Cabeza de Vaca, $1^{\circ} 38^{\prime} \mathrm{S}, 80^{\circ} 38^{\prime} \mathrm{W}, 26$ xi 1993, X. Cornejo \& C. Bonifaz 764 (AAU); Vicinity of río Ayampe, provincial boundary to Guayas, $1^{\circ} 42^{\prime} \mathrm{S}$, 8049’W, 7 xii 1985, J. Madsen 61182 (AAU [3]); Near Pajan, O.L. Haught 3090 (F, US [2]). Cotopaxi: Tenefuerste, río Pilaló, km 52-53, Quevedo-Latacunga, 12 vi 1983, C.H. Dodson et al. 13933 (F, MO, QCNE, SEL); Road Quevedo-Latacunga, below Macuchi, G. Harling et al. 9149 (F, MO, NY, US). Los Rios: San Antonio de Caluma, km 39, on the road Puebloviejo to Guaranda, forest remnants, $1^{\circ} 37^{\prime} \mathrm{S}, 7^{\circ} 18^{\prime} \mathrm{W}, 20$ iv 1980, L.B. Holm-Nielsen 22916 (AAU, MO). Bolivar: Vicinity of Echiandia, along road between Echiandia and Santa Lucia, $2.7 \mathrm{~km} \mathrm{~W}$ of Santa Lucia, $1^{\circ} 27^{\prime} \mathrm{S}, 7^{\circ} 13^{\prime} \mathrm{W}, 13$ viii 2004, T.B. Croat et al. 93304 (MO [2], QCNE); Balsapamba, Sodiro 596 (QPLS). Chimborazo: Without further locality, vii 1860, s.c., s.n. (K); Pallatanga Cantone, road between Bucay and Pallatanga, roadside cliff a few kms above Bucay, 19 i 2014, M.C. Tebbitt 794 (QCA); Between Huigra and Naranjapata, A.S. Hitchcock 20639 (NY, US); 20640 (NY, US). Guayas: Cerrato of Guayaquil, W. Jameson s.n. (K [bar code K000536582, mounted on same sheet as isotype collection]); Municipio Guayaquil, F.M. Valverde 305 (COL, US); Vicinity of Ventura [c. $\left.2^{\circ} 14^{\prime} \mathrm{S}, 79^{\circ} 9^{\prime} \mathrm{W}\right]$, J.N. Rose 23521 (NY, US [3]); Hacienda Piedad, $5 \mathrm{~km}$ N of Balzar, $1^{\circ} 20^{\prime} \mathrm{S}, 79^{\circ} 54^{\prime} \mathrm{W}, 16 \mathrm{v}$ 1968, L. Holm-Nielsen \& S. Jeppesen 27 (AAU, US); $3 \mathrm{~km}$ east of Olon ( $5 \mathrm{~km} \mathrm{~N}$ of Manglaralto on the beach) in humid valley [c. $\left.1^{\circ} 46^{\prime} \mathrm{S}, 80^{\circ} 46^{\prime} \mathrm{W}\right], 20$ xii 1961, C.H. Dodson \& L.B. Thien 1670 (MO, US); Santa Elena Cantón, Reserva Comunal Loma, $5 \mathrm{~km} \mathrm{NW}$ of Suspiro, $1^{\circ} 49^{\prime} \mathrm{S}, 80^{\circ} 36^{\prime} \mathrm{W}$, P.J.M. Maas et al. 8567 (K); Santa Elena Cantón, reserva Comunal Loma Alta, $5 \mathrm{~km}$ NW of Suspiro, $1^{\circ} 53^{\prime} \mathrm{S}$, $80^{\circ} 37^{\prime} \mathrm{W}, 22$ i 1997, $J$. Clark et al. 3861 (MO, QCNE, US); Along new road to military reservation, near top of Cerro Azul, a calcareous outlier of Cerros de Chongon, at $14 \mathrm{~km}$ on GuayaquilSalinas road ( $1 \mathrm{~km}$ before Barcelona), c. $18 \mathrm{~km} \mathrm{~W}$ of Guayaquil, c. $2^{\circ} 09^{\prime} \mathrm{S}, 80^{\circ} 02^{\prime} \mathrm{W}, 27-28$ vii 1977, H.H. Iltis \& F. Triviño E-608 (C, QCA, US); La Frutilla, Cerro de Isera near Julio Moreno, C. Játiva \& C. Epling 962 (S). El Oro: Piñas Cantone, small dirt road leading to Buenaventura Reserve, $3^{\circ} 39^{\prime} \mathrm{S}, 7^{\circ} 47^{\prime} \mathrm{W}, 16$ i 2014, M.C. Tebbitt 776 (QCA). Loja: Puyango Cantone, $3^{\circ} 54^{\prime} \mathrm{S}, 80^{\circ} 01^{\prime} \mathrm{W}, 15$ i 2014, M.C. Tebbitt 773 (QCA).

Peru. Tumbes: Prov. Zarumilla, Entre P. C. "El Couche" y P. C. Campoverde, Bosque Nacional de Tumbes, Reserva de Biósfera del Norveste, $3^{\circ} 50^{\prime} \mathrm{S}, 80^{\circ} 15^{\prime} \mathrm{W}, 8$ vii 1992, C. Díaz et al. 4708 (F, MO, NY, US, USM [2]).

Notes. Begonia serotina A.DC. is morphologically most similar to B. erythrocarpa A.DC. Both have thick aerial stems, large dichotomous cymes, and deciduous, peltate leaves. The two species are readily separated, most obviously by their leaf morphologies, since Begonia serotina has leaf blades that lack lobes, while those of B. erythrocarpa are deeply lobed. The ovaries of Begonia erythrocarpa also differ in having bracteoles, while those of $B$. serotina lack bracteoles. Begonia serotina is also similar to $B$. ludwigii Irmsch. but differs from this species by its growth habit (B. ludwigii has a much thicker, straighter and taller stem than $B$. serotina), peltate leaves (B. ludwigii always has non-peltate leaves) that lack a ruff of hairs where the petiole joins the blade (those of $B$. ludwigii have a characteristic ruff of hairs) and by the lack of ovary bracteoles (B. ludwigii has ovary bracteoles).

Begonia ludwigii Irmsch., Biblioth. Bot. 116: 113 (1937). - Type: Ecuador, Prov. Chimborazo, Tal des Rio Chanchan, bei Naranjapata, 25 ix 1933, L. Diels 1204 (holo B[2]!; photo US!). 
Begonia compacticaulis Irmsch., Bot. Jahrb. Syst. 74: 612 (1949). - Type: Ecuador, Prov. Chimborazo, Huigra, vii 1923, A.S. Hitchcock 20315 (holo US!; iso NY!), syn. nov.

Begonia ecuadoriensis auct. non Buxton: hort. ex Everett, J. New York Bot. Gard. 51: 4 (1940).

Begonia griseocaulis auct. non Irmsch.: L.B.Sm. \& B.G.Schub., Mem. New York Bot. Gard. 8: 38 (1952).

Begonia rigida auct. non Linden ex Regel: A.Clarke, The Begonian 14: 150 (1947).

\section{ACKNOWLEDGEMENTS}

We thank the curators of AAU, B, BKL, BM, BR, BRIT, C, CAS, CGE, COL, E, F, G, GB, GH, GOET, HUT, K, MO, NY, OXF, P, QCA, QCNE, QPLS, S, SEL, TEX, UC, US, W and Z for loaning material or allowing M.T. to work in their herbaria. We thank Mr Peter Moonlight for providing us with photographs of specimens housed at CPUN, MOL, MOL-WEB and USM. We thank the Ecuadorian Ministerio del Ambiente for granting us permission to conduct the fieldwork and collect specimens and the American Begonia Society for funding the fieldwork. We are grateful to Mr Jacky Duruisseau for bringing our attention to the population of Begonia serotina located in Ecuador's Loja Province and for revisiting some of the field sites to photograph $B$. ludwigii in flower. We also thank Ms Adèle Rossetti Morosini for providing the beautiful artwork.

\section{REFERENCES}

de Candolle, A. (1859). Mémoire sur la famille des Bégoniaceas. Ann. Sci. Nat., ser. 4 , Bot. 11: 93-115.

de Candolle, A. (1864). Begoniaceae. In: Prodromus Systematis Naturalis Regni Vegetabilis 15(1): 266-408. Paris: Victoris Masson et filii.

De Lange, A. \& Bouman, F. (1992). Seed micromorphology of the genus Begonia in Africa: taxonomic and ecological implications. Wageningen Agricultural University Papers 91-4.

De Lange, A. \& Bouman, F. (1999). Seed micromorphology of neotropical Begonias. Washington, DC: Smithsonian Institution Press.

Doorenbos, J., Sosef, M. S. M. \& De Wilde, J. J. F. E. (1998). The sections of Begonia including descriptions, keys, and species lists. Wageningen Agricultural University Papers 98-2.

Ir mscher, E. (1949). Beiträge zur Kenntnis der Begoniaceen Südamerikas. Bot. Jahrb. Syst. 74: 569-632.

IUCN (2012). The IUCN Red List of Threatened Species. Version 2012.2. http://www. iucnredlist.org.

Quintana, C. \& Pitman, N. (2003). Begonia serotina. The IUCN Red List of Threatened Species. Version 2014.1, http://www.iucnredlist.org, downloaded on 4 July 2014.

Smith, L. B. \& Wasshausen, D. C. (1979). Begonia of Ecuador. Phytologia 44(4): 233-256. 
Smith, L. B. \& Wasshausen, D. C. (1986). Begoniaceae. In: Harling, G. \& Andersson, L. (eds) Flora of Ecuador 25: 1-66. Stockholm: Swedish Research Councils. Tеввiтt, M. C. (2014). Begonias of the Western Andes of Ecuador. The Begonian 81(3): 134-139.

Received 26 August 2014; accepted for publication 27 January 2015; first published online 12 March 2015 